\title{
A VIZES SZOLGÁLTATÁSOK SZEREPE A TURISZTIKAI DESZTINÁCIÓ MEGVÁLASZTÁSÁBAN
}

Czeglédi Hanna Orsolya - Pucsok József Márton - Lenténé Puskás Andrea - Biró Melinda

\section{Összefoglalás}

Szabadidejükben vagy a nyári üdülések alkalmával az emberek szeretnének pihenni, kikapcsolódni, ellazulni, feltöltödni. A hasznos szabadidö-eltöltés, az élményszerzés, a kikapcsolódás és az egészségtudatosság egyre inkább megjelenik az emberek üdülöhely-megválasztását befolyásoló tényezöinél. Mivel ezek az üdülések során mint igény jelennek meg, ennek hatása a turisztikai desztinációk megválasztásakor is érvényesül. Kutatásunkban azt vizsgáltuk, hogy az emberek a nyári üdüléseik alkalmával milyen mértékben részesitik elönyben az egyes szolgáltatásokat (különféle vizes szolgáltatásokat, az egészségjavitó, az orvosi, a szabadidös, és egyéb szolgáltatásokat), és mi alapján választják meg a helyszint. Célunk megvizsgálni, hogy ezen elemek megléte milyen mértékben befolyásolja a válaszadók döntéseit az üdülések alkalmával a desztináció megválasztásában. A kvantitativv eljárás során elötesztelt kérdöivet alkalmaztunk, melyben jelen kutatáshoz kapcsolódó kérdéseink csak egy kis részét képezték a komplex vizsgálatnak. A kutatásban kizárólag az Eszak-Alföld régióban élö lakosok vettek részt, 270 fö. A minta 28,9\%-a férfi, a 71,1 \%-a nö. Eredményeink azt mutatták, hogy a vizsgált személyek motivációi eltéröek ugyan, de ennek ellenére vannak közös pontotok. Egyik ilyen a viz és a vizes szolgáltatások megléte. A viz közelsége (tenger, gyógyviz, strand stb.), az anyagiak, az ár-érték arány, látnivalók, az élmény, a kulturális programlehetöségek, a pihenés lehetösége és a szabadidös tevékenységek fontos szempont a desztináció választásában.

Kulcsszavak: vizes szolgáltatások, szabadidő, turisztikai desztináció, egészség JEL: 134Rce 


\title{
THE ROLE OF WATER SERVICES IN THE CHOICE OF TOURIST DESTINATION
}

\begin{abstract}
In their free time or during their summer holidays, people want to relax, unwind, relax, recharge. Spending useful leisure time, gaining experience, recreation, and health awareness are increasingly appearing in the factors that influence people's choice of resort. As these appear as a demand during the holidays, its effect is also present in the choice of tourist destinations. In our research, we examined the extent to which people prefer certain services (various water services, health, medical, leisure, and other services) during their summer vacations, and based on what they choose the location. Our aim is to examine the extent to which the presence of these elements influences respondents 'decisions on the choice of destination during their holidays. We used a pre-tested questionnaire during the quantitative procedure, in which our questions related To the present research were only a small part of the complex study. Only residents living in the Northern Great Plain region participated in the research, 270 people. $28.9 \%$ of the sample are male and $71.1 \%$ are female. Our results showed that although the motivations of the subjects differed, they nevertheless have something in common. One of these is the existence of water and water services. The proximity of the water (sea, medicinal water, beach, etc.) to the material, value for money, attractions, experience, cultural program opportunities, opportunities for recreation and leisure activities are important considerations in choosing a destination.
\end{abstract}

Keywords: water services, leisure, tourist destination, health JEL: 134Rce 


\section{Bevezetés}

A szabadidejüket az emberek szívesen töltik vízparton. Hazánkat még Európában is gyógyvíznagyhatalomként tartják számon, sőt ha a szűkebb hazánkat, az Észak-Alföld régiót vizsgáljuk, akkor azt mondhatjuk, hogy sehol máshol az országban nincs annyi strand, aquapark, élményfürdő, csúszdapark, fedett és fedetlen fürdőrészleg, mint ebben a régióban. Nem véletlen hogy a régió turizmusfejlesztési stratégiájában az egészségturizmus fejlesztése az első helyen álló prioritás, melyen belül a fürdőfejlesztések mint turisztikai attrakció fejlesztése fokozott figyelmet kap (Könyves et al., 2005; Müller-Könyves, 2006; Müller et al., 2009; Árpási 2014; Müller-Bácsné, 2018; Lenténé et al., 2019a,b). Ennek eredményeként új fürdők jöttek létre, a már meglévő fürdők esetében a vízfelületet növelték, minőségi fejlesztéseket hajtottak végre, ami a környezet dizájnelemeit is érintette. A fürdőfejlesztések során a szolgáltatásbővítés is igen fontos szerepet kapott, hiszen olyan új kínálati elemek jelentek meg (Müller et al., 2016; Biró et al., 2018a,b; Biró et al., 2019b). Ezek egyik eredményeként megnőtt a fürdők kereslete, és a vendégforgalom (Biró et al., 2018; Biró et al., 2019b). Az Észak-Alföld régióban található fürdők vendégforgalma 2010-ben 5075 volt, míg 2012-re megközelítette a 6000 látogatót (5824). 2016-ban és 2017ben pedig már jóval 6000 fölött volt. A Központi Statisztikai Hivatal adatai is a fürdővárosok évről évre növekvő turisztikai vonzerejét mutatják. Országos szinten megközelítőleg 6\%-kal nőtt a fürdők látogatószáma 2016-ban az egy évvel korábbihoz képest (KSH). A pozitív változás egy kivétellel (Észak-Magyarország régió) Magyarország valamennyi régiójában érzékelhető volt. Mivel a fürdők száma és a vízfelület 2014-ről 2016-ra csökkent, viszont a fürdők több vendéget fogadtak, így növekedett az egy négyzetméter vízfelületre jutó vendégek száma (Biró et al., 2018; Biró et al., 2019b).

A fürdők, a strandok nagyon gyakran a nyári üdülések, és a szabadidő-eltöltések célpontjai (Müller et al., 2009; Müller-Szabó, 2009). Napjaink rohanó életmódja mellett szükség van időnként kikapcsolódásra a lakóhelyünkön vagy a nyári üdülések során attól távolabb is (Müller-Bácsné, 2018). A vízpart, a strandok, fürdők látogatása fokozatosan beépült a mindennapok programjába, mivel lehetőséget kínál a szabadidő eltöltésére, emellett a rendszeres testedzésre, a testápolásra, a kikapcsolódásra és nem utolsó sorban a pihenésre. A fürdők ma már nem csupán az évi rendes fonnyaralás helyszínei, hanem az általános jó közérzet, a test és a szellem egészsége megőrzésének, a rekreációnak a helyszíne is (Müller et al., 2009). Az utazási motivációkban is egyre erősödik a sportmotiváció (Tütünkov et al., 2020). A szabadidejükben az emberek egyre inkább nyitottá váltak az egészségmegőrzésre és az új élmények szerzésére (Borbély-Müller, 2015; Bujdosó-Pénzes, 2015; Lenténé et al., 2018; Lenténé et al., 2019c; Biró et al., 2019a; Hidvégi et al., 2019a,b; Fenyves et al., 2020; Makra- 
Balogh, 2020). Felmerül a kérdés, hogy mennyi szabadidővel rendelkeznek az emberek. A 15-74 éves népesség körében átlagosan 266 perc állt rendelkezésre naponta a szabadidős tevékenységekre (KSH 2009/2010).

Egy társadalomról sokat elárul a szabadidő-kultúrája. Egy országot - úgy, mint az egyént is - a szabadidőtöltés módjából lehet megismerni - fogalmaz DobozyJakabházy (1992). A szabadidőt sokféle módon fel lehet használni, aminek egyik módja az aktív fizikai tevékenység végzésével járó, míg a másik a passzív szabadidőeltöltés (Bácsné et al., 2018). Az Egészségjelentés (2015) szerint viszont sajnos hazánkban a szabadidő eltöltésekor a fizikai aktivitás még mindig nem élvez prioritást. A szabadidős tevékenységségeket tehát két részre oszthatjuk, aktív és passzív pihenésre. A szabadidős tevékenységek listáján az első helyen 2010-ben a televíziónézés szerepelt, kimagasló arányban 83\%-kal. (Növekvő tendenciát mutat az internetezés, amit sokszor együtt is említenek a televízióval és a videózással.) A második helyen a társas szabadidőtöltés áll 54\%-kal. Ezt követi az olvasás (26\%), majd a sporttevékenységek (17\%), amelyekbe beleszámít a séta és a kirándulás. Az aktív és passzív pihenésben változásokat tapasztalhatunk. A Nemzeti Sportstratégiában (2007-2013) olvashatjuk, hogy a felnőtt lakosság 16\%-a mozog szabadidejében, ha szűkebb értelemben vizsgáljuk (hetente minimum két alkalom fél órás aktivitással), akkor azonban ez az országos adat 9\%-ra esik. Ezt követi a baráti összejövetel 15\%-os aránnyal. A harmadik legnépszerűbb tevékenység a kirándulás 14\%-kal. A további aktív tevékenységek - a játék (12\%), kézművesség $(6 \%)$, meditáció (3\%), kutató tevékenység $(5 \%)$, a tánc $(6 \%)$, a tanulás $(6 \%)$, rajz (4\%), egyéb (4\%) - arányosan oszlanak meg. Abban az esetben, ha a KSH 2015-ös kutatásait tekintjük, az eredmények nagymértékben eltérnek. Ugyanakkor minden téren visszaesést vélünk felfedezni a televíziózás, videózás, internetezés $(57,1 \%)$, a társas szabadidő (18\%), olvasás $(7,5 \%)$, sport, séta, testedzés (5,6\%) kategóriáknál. Az Eurobarometer 2017-es kutatásából az derül ki, hogy a lakosság 33\%-a sportol mindennap vagy rendszeresen. A férfiak és nők szabadidős szokásai nagymértékủ eltérést mutatnak, azonban a sport mindkét nemnél az első helyen áll. A nőknél 55\%, míg a férfiaknál 66\%. A hölgyeknél megegyezik a második helyen két tevékenység, a természetjárás és a társas összejövetel. Mindeközben a férfiaknál 45\%-ban a játék jelenik meg, és csak a harmadik helyen a társas összejövetel. 2018-as saját kutatásaink (Horkay et al.; 2018a,b) pedig azt mutatják, hogy az emberek többségénél az internethasználat a legjellemzőbb szabadidős tevékenységi forma, a passzív tevékenységek között, ezt követi az olvasás és keresztrejtvény-fejtés.

Látható, hogy a mozgással töltött idő a férfiak és a nők esetében is nagymértékben növekedett (Bujdosó-Remenyik, 2008). Meg kell jegyeznünk azonban, hogy az európai átlagtól mégis 4\%-kal lemaradtunk a sportolási szokásinkat tekintve. Mi játszik ebben szerepet? A válasz erre az, hogy mindez nagyon összetett. Egyfelől függ az életkortól, hiszen a mozgás, a rekreációs tevékenység és a szabadidő eltöltése különbözik 
életkoronként (Boda et al., 2015; Juhász et al., 2015; Boda et al., 2019). Más sajátosságokat mutat fiataloknál (Czabai et al., 2007; Boda et al., 2016) felnőtteknél és időseknél (Csörgő et al., 2013; Kopkáné et al., 2015; Juhász et al., 2015).

Ezért is vállalkoztunk arra, hogy kutatásunkban egyrészt megvizsgáljuk, hogy az emberek mennyi szabadidővel rendelkeznek, és ebből mennyit fordítanak aktív pihenésre, mozgásra, sportra, másfelől pedig megnézzük, hogy a szabadidejükben milyen mértékben választják a vizes szolgáltatásokat. Mivel az országos adatok azt mutatják, hogy a szabadidő eltöltésében a - belföldi, turisztikai célú többnapos utazások adatait vizsgálva - szórakozás, a pihenés és az egészségmegőrzés a legmeghatározóbb (KSH 2019), így kíváncsiak voltunk arra, hogy mindez miként jelenik meg az utazás helyszínének kiválasztásában. Jelen tanulmányunkban leginkább a vizes szolgáltatásokra koncentráltunk, így ennek eredményeit kívánjuk bemutatni.

\section{Anyag és módszer}

Kutatásunk során az vizsgáltuk, hogy a nyári üdüléseik alkalmával milyen mértékben részesítik előnyben az emberek az egyes szolgáltatásokat, és mi alapján választják meg a helyszínt. Természetesen kíváncsiak voltunk, hogy a helyszín megválasztásakor a különféle vizes szolgáltatások, az egészségjavító, az orvosi, a szabadidős és egyéb szolgáltatások milyen szerepet kapnak a helyszín megválasztásában. Célunk megvizsgálni, hogy ezen kínálati elemek megléte milyen mértékben befolyásolják a válaszadók döntéseit az üdülések alkalmával a desztináció megválasztásában. A kvantitatív eljárás során előtesztelt kérdőívet alkalmaztunk, melyben számos szolgáltatás felmérése szerepelt, így a desztináció megválasztásával kapcsolatos szolgáltatások felmérése csak egy kis részét képezte a komplex vizsgálatnak. Az alábbi témakörök kaptak helyet a kérdőívben: az egészségmegőrzés lehetőségei, a vizes szolgáltatások, sport és szabadidős, valamint az úszás egészségre gyakorolt hatásának vizsgálata. Jelen tanulmányunkban kizárólag azt kívánjuk bemutatni, hogy a vizes szolgáltatások milyen mértékben befolyásolják a válaszadók döntéseit az üdülések alkalmával a desztináció megválasztásában. A kutatásban kizárólag az Észak-Alföld régióban élő lakosok vettek részt, 270 fö. A minta 28,9\%-a férfi, a 71,1\%-a nő. Átlagéletkor: 28,3 év. A vizsgálatban résztvevők saját bevallása szerint 31,5\%-uk nem sportol, míg 68,5\%-uk igen. A vizsgálatban résztvevők többsége egészségesnek érzi magát (1-től 5-ig Likertskálán vizsgálva, ahol az egyes jelentése nem, ötös értéke teljes mértékben, átlag: 3,83, szórás: 0,77$)$. A megkérdezettek szerint a sport, a mozgás fontos szerepet játszik az egészséges életmódban (1-től 5-ig Likert-skálán vizsgálva, átlag: 4,53, szórás: 0,68). 


\section{Eredmények}

\section{A szabadidö-eltöltés módja}

A kutatásaink azt mutatják, hogy a vizsgálatban résztvevők zöme, 37\%-a napi 3-4 óra, míg 35\%-a napi 1-2 óra szabadidővel rendelkezik. 11,5\%-uknak egy óránál is kevesebb a szabadideje, míg 1,5\%-uk vallotta azt, hogy nem is rendelkezik vele. 11,9 \%-uk napi 5-6 óra, míg 3\%-uk 6 óránál is több szabadidővel bír. Érdekes képet mutat az, hogy mivel is töltik a szabadidejüket az emberek. Az eredményeink azt mutatják, hogy a vizsgálatban résztvevők $46,9 \%$-a aktív pihenéssel tölti szabadidejét, míg 46,7\%-uk passzív pihenéssel, 37,8\%-uk mozgásos aktivitással, 14,6\%-uk pedig egyéb tevékenységgel. Mivel a kérdőív ezen kérdésénél, több választ is meg lehetett jelölni, így megvizsgáltuk a további eredményeket is, hiszen mindez nem mutatja a valós képet. Sokan a mozgás mellett pihenhetnek, olvashatnak is, és azok, akik leginkább a passzív pihenést választják, ugyancsak mozoghatnak. Így részletesebben vizsgálva azt kaptuk, hogy a résztvevők 21,1\%-a kizárólag az aktív pihenést választja, 22,2\%-uk pedig a passzívat, de többségük a kettő kombinációját alkalmazza. 9,2\%uk az aktív szabadidős tevékenységében sportol is, 6,3\%-uk az aktív és a passzív pihenést egyaránt választja, míg passzív tevékenységet jelölők 8,9\%-a mozog. Azok, akik a passzív és az aktív tevékenységet, valamint a mozgást is jelölték, a minta 16,4\%-át tették ki.

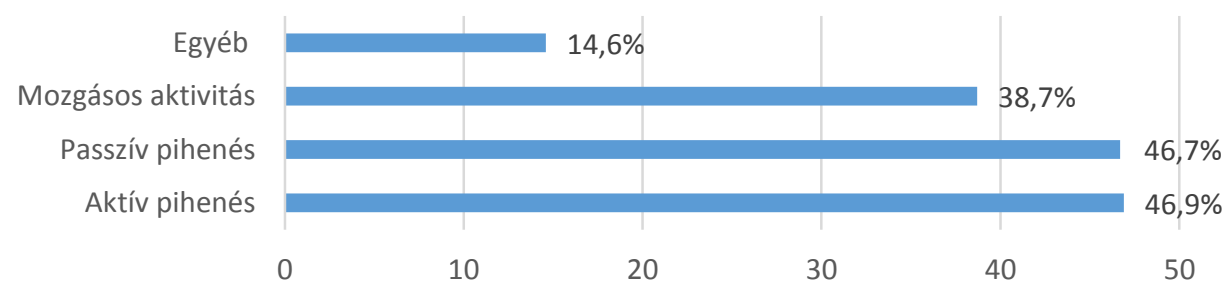

1. ábra: A kutatásban résztvevők szabadidős tevékenységeinek megoszlása százalékban $(\mathbf{n}=271)$

Forrás: saját kutatás, saját szerkesztés

\section{Vizes, gyógyvizes és egészségjavitó szolgáltatások}

A régióban páratlan gazdagságban előforduló gyógyhatású termálvizekre alapozott beruházások realizálódtak, 2000 óta jelentős volt a termál- és gyógyvízre alapozott turisztikai fejlesztés, amelyek eredményeként mára a régió egészségturisztikai kínálata országos szinten is kiemelkedő (Biró et al., 2018, Biró et al., 2019b). A támogatások 66\%-ban a termálfürdők, gyógyvizek fejlesztéséhez kapcsolódtak, döntően Hajdú- 
Bihar megyében (Könyves-Müller, 2007; Müller-Szabó, 2009; Bujdosó, 2009). Érdekes eredményeket kapunk, ha megvizsgáljuk, hogy az egyes szolgáltatási kategóriák, mint például a vizes szolgáltatások, a gyógyvíz megléte vagy az egészségjavító és orvosi szolgáltatások milyen mértékben játszanak szerepet a nyári üdülések helyszínének megválasztásakor. A vizes szolgáltatások leginkább a fontos (30\%), és a nagyon fontos (18,5\%) kategóriába kerültek, és 24,5\%-ban a részben fontosba. Mindössze a válaszadók 26,7\%-ánál elhanyagolható vagy egyáltalán nem lényeges. Látható, hogy a gyógyvizes szolgáltatások kis mértékben dominálnak, 20\%-ban kerülnek a fontos szempont közé (12,6\% fontos, 7,4\% nagyon fontos). A válaszadók többségénél, 52,5\%-uknál (18,1 egyáltalán nem, 34,4 elhanyagolható) nem játszik szerepet, míg 27,4\%-uknál csak részben. A válaszadók 12,6\%-ánál fontos szempont, 7,4\%-uknál pedig nagyon lényeges. Az egészségjavító szolgáltatások a válaszadók 16,3\%-ánál egyáltalán nem fontosak, 31,1\%-uknál elhanyagolható szempont az üdülés helyszínének megválasztásakor. Mindössze 24,5\%-uk tartja lényegesnek (16,7\% fontos, 7,8\%, nagyon fontos), hogy legyen ilyen szolgáltatás az üdülés helyszínén. Mint látható (2. ábra), az orvosi szolgáltatások szerepe lényegesebb. A válaszadók 35,9\%-a szerint ez lényeges (16,3\% fontos, 19,6\%, nagyon fontos). 48,5 \%-uk szerint lényeges szempont az üdülés helyszínének megválasztásakor (30\% fontos, 19,6\%, nagyon fontos).

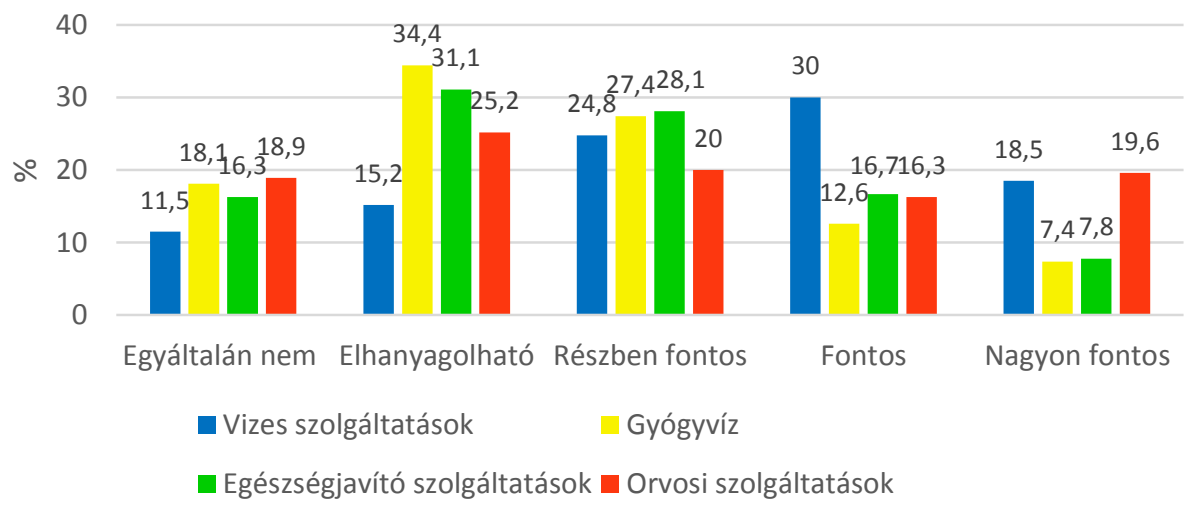
2. ábra: Az Észak-Alföld régió lakosságának nyári üdüléseit befolyásoló szem- pontok százalékos eredményei $(\mathrm{n}=271)$
Forrás: saját kutatás és szerkesztés

Mivel a kitöltők 63,2\%-a 25 évnél fiatalabb, 28,25\%-uk 25 és 50 év közötti, és mindössze 8,5\%-uk 50 év feletti, így talán nem meglepőek az eredmények. Feltételeztük, hogy a gyógyvizes szolgáltatást fóként a középkorúak és az idősebbek körében kedvelt. Az 50 év feletti válaszadók közül meglepve tapasztaltuk, hogy többségüknél $(58,2 \%)$ elhanyagolható vagy egyáltalán nem szempont a választáskor. Mindössze 
29,1\%-uknál számít lényegesnek a desztinációválasztásban. Az egészségjavító szolgáltatások hasonló eredményt mutattak az 50 év feletti mintában. A válaszadók közel felénél, a 37,4 \%-uknál már a lényeges kategóriába kerül, 16,6\% nagyon fontosnak, 20,8\% fontosnak értékeli ezek meglétét a választáskor. Ugyancsak érdekes megállapítás, hogy az orvosi szolgáltatásokat az 50 év felettiek egyáltalán nem tartják lényeges választási szempontnak (62,4\%) 45,8\%-uk egyáltalán nem fontos, míg 16,6\%-uk az elhanyagolható válaszokat adta. Mindössze az 50 év felettiek 16,6\%-ánál számított a fontos, és ugyanennyi százalékuknál a nagyon fontos kategóriába.

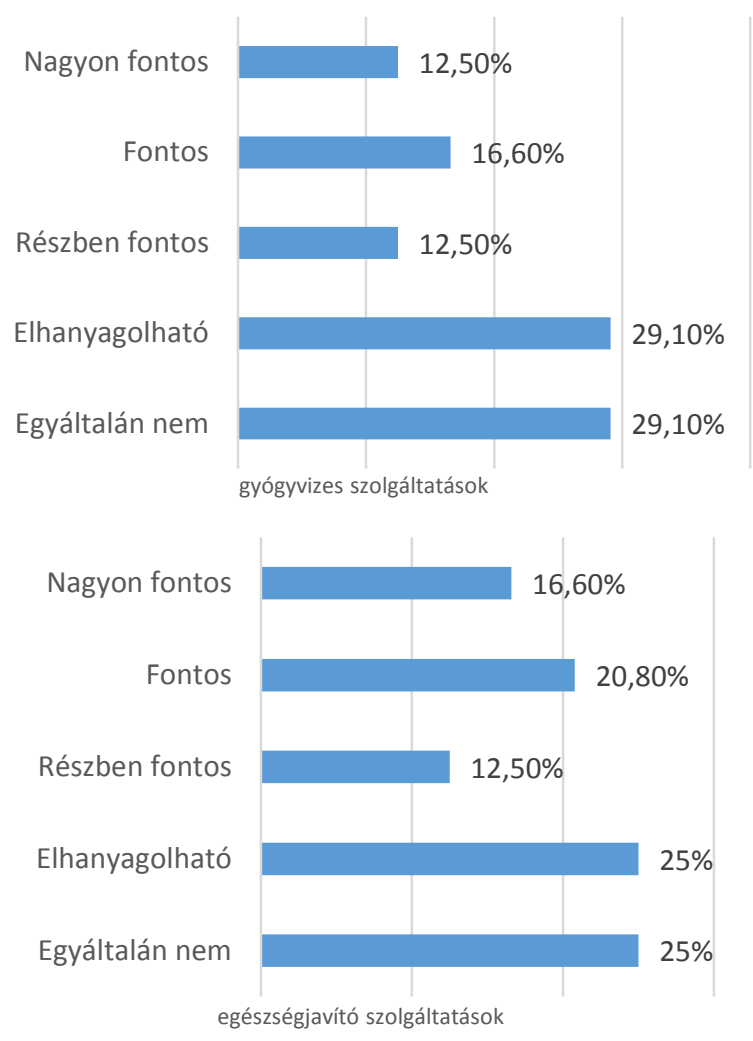

3. ábra: Az Észak-Alföldi régió lakosságának nyári üdüléseit befolyásoló szempontok százalékos eredményei az 50 év feletti lakosoknál, a gyógyvizes és az egészségjavító szolgáltatások tekintetében

Forrás: saját kutatás és szerkesztés 


\section{Strand- és élményfürdö-szolgáltatások}

Az Észak-Alföld régióban számos közkedvelt fürdő található, a legismertebb a Hajdúszoboszlói Gyógy- és Élményfürdő, ami Európa legnagyobb fürdőkomplexuma. A régió fürdőinek száma 2010-ről 2013-ra növekedést mutatott, majd ez a növekedés megállt, és lassú csökkenés következett be 2014 és 2016 között. Napjainkra már nem a fürdők száma emelkedik, hanem a meglévő fürdők kínálatának fejlesztése figyelhető meg. Az Észak-Alföld régióban található fürdők kereslete és vendégforgalma folyamatosan nő, 2010-ben 5075 volt, míg 2012-re megközelítette a 6000 látogatót, 2016-ban és 2017-ben pedig már jóval 6000 fölött volt. A fürdők növekvő keresletet elégítenek ki, és évről évre növekvő turisztikai vonzerőt jelentenek (Biró et al., 2018, Biró et al., 2019b). A vizsgálatban résztvevők többségének, 65,2\%-ának, (35,3\% fontos, 30\% nagyon fontos) lényeges a strand jelenléte. Ezzel szemben az élményfürdő-szolgáltatások is azt mutatják, hogy fontos tényezők közé sorolják őket, a válaszadók 46,3\%-a számára lényeges (26,3 fontos, 20\% nagyon fontos) szempont ez a desztináció megválasztásában. Megfigyelhető hogy a két lehetőség közül az elhanyagolhatóság inkább az élményfürdő-szolgáltatásokra jellemző 29,6 \%-kal (13,3\% egyáltalán nem, 16,3\% elhanyagolható).

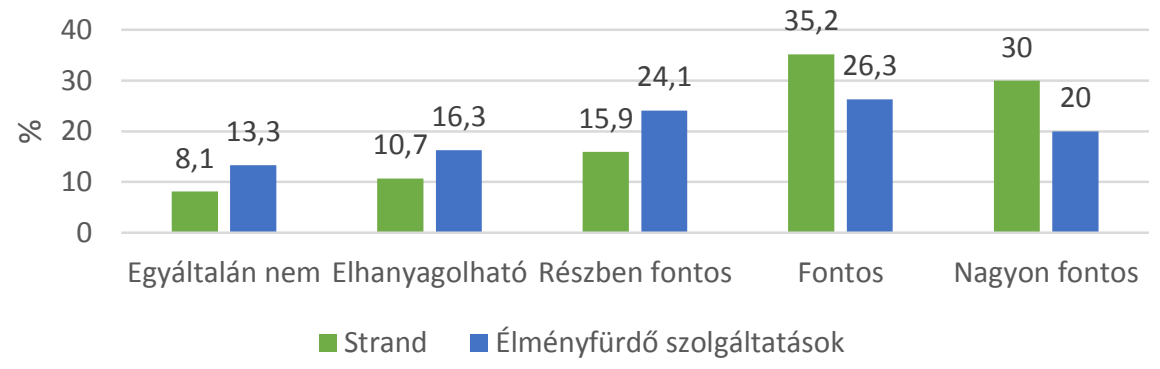

4. ábra: Az Észak-Alföld régió lakosságának nyári üdüléseit befolyásoló szempontok százalékos eredményei a strand- és élményfürdő-szolgáltatások tekintetében $(\mathbf{n}=271)$

Forrás: saját kutatás és szerkesztés

\section{Szabadidös szolgáltatások}

A szolgáltatók kiválasztását a szabadidős szolgáltatások is befolyásolják. A szabadidős szolgáltatások növekvő keresletét mutatja, hogy a vizsgálatban résztvevők többségénél, 73,4\%-uknál lényeges (34,1\% fontos 39,3 nagyon fontos) ezen szolgáltatások megléte. Ha az öt kategóriát vizsgáljuk, akkor csak 14\% (7\% egyáltalán nem, 7\% elhanyagolható) mondja azt, hogy nem olyan fontos a szabadidős szolgáltatások kínálata a számára a desztináció választásakor, míg 12,2\%-uknál részben fontos. 


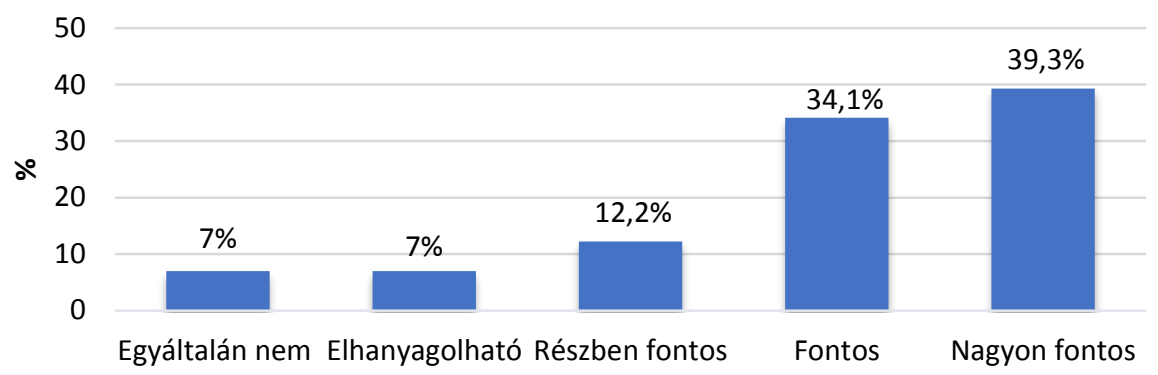

5. ábra: A szabadidős szolgáltatások fontossága a nyári üdülések helyszínének választásnál, százalékban $(\mathrm{n}=271)$

Forrás: saját kutatás és szerkesztés

\section{Az utazási helyszín megválasztásának fó motivációi}

A válaszadókat nyilt kérdés formájában kérdeztük meg arról, hogy mi alapján választják meg a nyári üdülés helyszínét. Az eredmények alapján kategóriákat képeztünk, és ennek megfelelően értékeltünk. Eredményeink azt mutatják, hogy a vizsgált személyek motivációi eltérőek ugyan, de ennek ellenére vannak közös pontok. Egyik ilyen a víz, míg a másik az anyagiak. A megkérdezettek $25 \%$-a írta, hogy a víz közelsége (tenger, gyógyvíz, strand stb.) fontos szempont a desztináció választásában. A válaszadók 18\%-a jelölte még azt, hogy az anyagi helyzetük, az ár-érték arány, illetve az anyagi lehetőségeik azok, amelyek leginkább befolyásolják a helyszín kiválasztását. A válaszadók 17,34\%-a a látnivalók, az élmény, a kulturális programlehetőségek, a pihenés lehetősége és a szabadidős tevékenységek miatt választja az adott helyszínt. 5,53\%-uk a természet közelségét (hegyek, turistalehetőségek) jelölte, míg 6,27\%-uk a megközelíthetőséget és a közelséget tartotta fontos szempontnak.

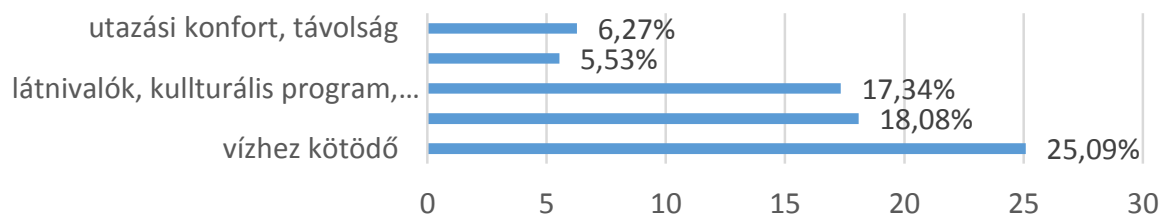

6. ábra: Az utazási helyszín megválasztásának fó motivációinak

százalékos értéke $(\mathrm{n}=271)$

Forrás: saját kutatás és szerkesztés

Mint ahogy már említettük, az 50 feletti lakosság körében úgy véltük, hogy a desztináció választásában fontos szempont lesz az egészségjavító, orvosi szolgáltatások 
megléte vagy a gyógyvíz. Ennek ellenére az eredményeink azt mutatták, hogy ez csak részben igaz, az 50 év feletti válaszadók kisebb hányada tartja fontosnak ezek meglétét. Így felmerül bennünk további kérdésként, hogy akkor mégis mi lehet lényeges szempont számukra. Nyílt kérdésben vizsgálva az adott válaszokat, tartalmi kategóriánként csoportosítottuk azokat, és ez alapján azt állapítottuk meg, hogy a vizes szolgáltatások megléte az 50 feletti korosztálynál lényeges választási szempont. Az 50 év felettiek 41,6\%-a írta a víz és a vízhez kötődő szolgáltatások fontosságát. 12,5\%-uk a természethez kötődő tényezőket (környezet, hegyi túra, természet stb.), és ugyancsak 12,5\%-uk az élményhez kapcsolódó (látnivalók, élmény) tényezőket írta. 8\%uk kiemelte a helyszín választásakor azt, hogy legyen közel (utazási komfort), és ugyancsak ennyien jelölték az anyagiakat is.

\section{Összegzés}

Mind hazánk, mind pedig az Észak-Alföld régió kiemelkedik a vizes szolgáltatások tekintetében. Mindez megmutatkozik a fürdők vendégforgalmában, és azok évről évre növekvő turisztikai vonzerejében. A fürdők, a strandok nagyon gyakran a nyári üdülések eltöltésének a helyszínei, valamint a szabadidő-eltöltések célpontjai. Így felmerül bennünk a kérdés, hogy miként jelenik meg az utazás helyszínének kiválasztásában a nyári üdülések alkalmával a víz és a vizes szolgáltatás. Kutatásunk eredményei azt mutatták, hogy a nyári üdüléseik alkalmával az emberek többsége életkortól függetlenül nagymértékben részesíti előnyben a víz (tenger, strand, medence) és a vízhez kötődő szolgáltatás meglétét az üdülés helyszínének megválasztásakor. A gyógyvizes szolgáltatások, az egészségjavító szolgáltatások kismértékben dominálnak, a válaszadók többségénél nem játszanak szerepet az üdülés helyszínének megválasztásakor. $\mathrm{Az}$ orvosi szolgáltatások szerepe lényegesebb, de nem olyan mértékű, mint a strand megléte. A vizsgálatban résztvevők többsége, 65,2\%-uk számára lényeges szempont, hogy az üdülés alkalmával legyen strand a közelben. Ugyancsak fontos tényezők közé tartozik az élményfürdő-szolgáltatások megléte is, a válaszadók 46,3\%-a számára lényeges szempont ez a desztináció megválasztásában. A szolgáltatók kiválasztását a szabadidős szolgáltatások is befolyásolják. A szabadidős szolgáltatások növekvő keresletét mutatja, hogy a vizsgálatban résztvevők többségénél, 73,4\%-uknál ugyancsak lényeges ezen szolgáltatások megléte. 


\section{Köszönetnyilvánítás}

A publikáció elkészítését az EFOP-3.6.2-16-2017-00003 számú projekt támogatta. A projekt az Európai Unió támogatásával, az Európai Szociális Alap társfinanszírozásával valósult meg.

\section{Hivatkozott források}

[1.] Árpási Z. (2014): Wellness turisztikai szolgáltatások fejlesztésének lehetőségei a Dél-alföldi régióban. [PhD-értekezés].

Forrás: https://szie.hu/file/tti/archivum/Arpasi_Zoltan_ertekezes.pdf

[2.] Bácsné, Bába É. - Balogh, R. - Bács, Z. - Fenyves, V. - Dajnoki, K. (2018): Sportszolgáltatások keresleti, kínálati oldalának elemzési lehetőségei. Studia Mundi - Economica, 5. évf. 3. sz. 19-33.

DOI: $10.18531 /$ Studia.Mundi.2018.05.03.19-33

[3.] Biró M. - Tatár A. - Pucsok J. M. - Lenténé Puskás A. - Mikhárdi S. Hidvégi P. - Molnár A. (2019a): Az Észak-alföldi régió szállodáinak egészségturisztikai trendjei. In: Balogh László (szerk.): Sokoldalú sporttudomány. Debrecen, Debreceni Egyetem Sporttudományi Koordinációs Intézet, 9-20. o.

[4.] Biró M. - Pucsok J. M. - Hidvégi P. - Molnár A. - Mikhárdi S. - Lenténé Puskás A. (2019b): A magyarországi és az Észak-alföldi fürdők jellemzőinek, forgalmának és a fürdők által nyújtott szolgáltatásoknak az elemzése. In: Balogh László (szerk.): Sport és társadalom. Debrecen, Debreceni Egyetem Sporttudományi Koordinációs Intézet, 18-28.

[5.] Biró M. - Lenténé P. A. - Bácsné B. É. - Müller A. (2018b): Role of the northern great plain region baths in wellness tourism and recreation in Hungary. Slovak Journal of Sport Science, 3. évf. 1. sz. 48-62. p.

[6.] Biró M. - Lenténé Puskás A. - Dobay B. - Müller A. (2018): Az Északalföldi fürdők szerepe a wellness turizmusban. In: Balogh, László (szerk.) Fókuszban az egészség. Debrecen, Debreceni Egyetem Sporttudományi Koordinációs Intézet, 38-49. o.

[7.] Boda E. - Honfi L. - Bíró M. - Révész L. - Müller A. (2015): A szabadidő eltöltésének és a rekreációs tevékenységek vizsgálata egri lakosok körében. Acta Academiae Paedagogicae Agriensis Nova Series: Sectio Sport, Vol. 42. 49-62. o.

[8.] Boda E. J. - Müller A. - Biró M. - Széles-Kovács Gy. - Nagy Zs. Ráthonyi-Ódor K. - Lengyelné H. A. - Dobay B. - Hidvégi P. (2016): A study on attitude to health among kindergarten children. In: Bendíková, E. 
- Mičko, P. (Eds.) Physical Activity, Health And Prevention: International Scientific Conference: Conference Textbook of Invited Lectures. Banská Bystrica, Matej Bel University Faculty of Arts, Department of Physical Education and Sports, 15-24. p.

[9.] Boda E. J. - Bácsné B. É. - Laoues-Czimbalmos N. - Müller, A. (2019): Rekreációs fogyasztói szokások vizsgálata magyar fiatal felnőttek körében. Különleges Bánásmód, 5. évf. 4. évf. 33-44. o.

[10.] Borbély A. - Müller A. (2015): Sport és turizmus. Debrecen, Campus Kiadó, $110 \mathrm{p}$.

[11.] Bujdosó Z. - Remenyik B. (2008): A hazai turisták életminőségének a feltérképezése az Észak-Magyarország Régióban. In: Dávid L. (szerk.) A turizmus szerepe az Észak-Magyarország Régióban I-II. Gyöngyös, Károly Róbert Föiskola, 40-48. o.

[12.] Bujdosó Z. (2009): A megyehatár hatása a városok vonzáskörzetére HajdúBihar megye példáján Debrecen, Debreceni Egyetemi Kiadó, 211 p.

[13.] Bujdosó Z. - Pénzes J. (2015): Tourism competitiveness and tourism development in the border regions of Hungary. In: Trukhachev, V. (Ed.) Sustainable Development of Tourism Market: International Practices and Russian Experience. Stavropol, Stavropol State Agrarian University, 18-26. p.

[14.] Czabai V. - Biró M. - Hajdu P. (2007): Az Eszterházy Károly Főiskola hallgatóinak életmódja, sportolási szokásai. Acta Academiae Paedagogicae Agriensis Nova Series: Sectio Sport, Vol. 34. 29-38. p.

[15.] Csörgő T. - Biró M. - Kopkáné P. J. - Müller A. (2013): Masszázsterápia hatásának vizsgálata hatvan év feletti nők körében. Acta Academiae Paedagogicae Agriensis Nova Series: Sectio Sport, Vol. 40. 5-16. o.

[16.] Dobozy L. - Jakabházy L. (1992): Sportrekreáció. Budapest, Magyar Testnevelési Egyetem, 2012 o.

[17.] EUROBAROMETER (2010): Sport and Phisical Activity. Letöltés dátuma: 2020. 04. 08., forrás: http://ec.europa.eu/public_opinion/archives/ebs/ebs_334_fact_hu_en.pdf

[18.] EUROBAROMETER (2014): Sport and Phisical Activity. Letöltés dátuma: 2020. 04. 08., forrás:

http://ec.europa.eu/public_opinion/archives/ebs/ebs_412_en.pdf

[19.] EUROBAROMETER (2017): Letöltés dátuma: 2020. 05. 01., forrás: https://ec.europa.eu/hungary/news/20171220_eurobarometer_hu

[20.] Fenyves V. - Bácsné Bába É. - Nagy A. (2020): Közösségben jobb sportolni! A debreceni Campus Sportfesztivál résztvevőinek vizsgálata. Debreceni Szemle, 28. évf. 1. sz. 112-126. o.

[21.] Hidvégi P. - Biró M. - Lenténé Puskás A. - Pucsok J. M. - Tatár A. Bárdos K. (2019a): Wellness szolgáltatást igénybevevők felmérése az Észak- 
alföldi régióban In: Balogh, László (szerk.) Sokoldalú sporttudomány. Debrecen, Debreceni Egyetem Sporttudományi Koordinációs Intézet, 1-8. o.

[22.] Hidvégi P. - Biró M. - Lenténé Puskás A. - Pucsok J. M. - Tatár A. (2019b): Az Észak-Alföld, mint turisztikai régió gyógy- és wellness turizmus, örökségturizmus. In: Balogh, László (szerk.) Sokoldalú sporttudomány. Debrecen, Debreceni Egyetem Sporttudományi Koordinációs Intézet, 2128. o.

[23.] Horkay B. - Lenténé Puskás A. - Biró M. (2018a). The supply elements and the recreational possibilities in the city and in the countryside. In: Šimonek, J. - Dobay B. (szerk.): Sport science in motion : proceedings from the scientific conference. Športová veda v pohybe: recenzovaný zborník vedeckých a odborných prác z konferencie = Mozgásban a sporttudomány: válogatott tanulmányok a konferenciáról. Komárno, Szlovákia, Univerzita J. Selyeho, 330-339. o.

[24.] Horkay B. - Lenténé Puskás A. - Biró M. (2018b): A város és vidék kínálati elemeinek és szabadidős lehetőségeinek összehasonlítása egy vizsgálat tükrében. In: Balogh L. (szerk.): Fókuszban az egészség. Debrecen, Debreceni Egyetem Sporttudományi Koordinációs Intézet, 94-105.

[25.] Juhász I. - Kopkáné P. J. - Kiszela K. - Biró M. - Müller A. - Révész L. (2015): Időskorúak rekreációs fizikai aktivitásának hatása a kardiorespiratorikus rendszerre. Magyar Sporttudományi Szemle, 16. évf. 63. sz. 4-8. o.

[26.] Kenyeres A. Z. - Juhász E. (2017): A kulturális közfoglalkoztatottak szabadidős kulturális aktivitásai. Kulturális Szemle, 4. évf. 2. sz. 25-41 o. Letöltés dátuma: 2020. 04. 15., forrás:

http://www.kulturalisszemle.hu/storage/upload/Kulturalis\%20Szemle\%20 8/KulturalisSzemle_2017_2.pdf\#page=25

[27.] Kopkáné P. J. - Juhász I. - Biró M. - Fodor É. - Révész L. (2015): Egerben élő nyugdíjasok egészségi állapotának és testedzési szokásainak vizsgálata. Acta Academiae Paedagogicae Agriensis Nova Series: Sectio Sport, Vol. 42. 27-36.

[28.] Könyves E. - Müller A. - Szalay F. - Szabó R. (2005): Cserkeszőlő és Karcag egészség-turizmusának összehasonlító elemzése. Szolnoki Tudományos Közlemények, Vol. 9. Paper: 9.

[29.] Könyves E. - Müller A. (2007). Az Észak-alföldi régió Turizmusfejlesztési stratégiája 2007-2013. In: Fejlesztés és képzés a turizmusban. II. Országos Turisztikai Konferencia tudományos közleményei. PTE, Pécs. [CD]

[30.] Központi Statisztikai Hivatal (2010): A 15-74 éves népesség napi időfelhasználása, 2010. A 2009/2010. évi időmérleg-vizsgálat összefoglalói alapján. Letöltés dátuma: 2020. 04. 08., forrás: 
http://www.ksh.hu/docs/hun/xftp/stattukor/idomerleg10.pdf

[31.] Központi Statisztikai Hivatal (2010): Kulturálódási szokásaink A lakosság televíziózásai, olvasási jellemzőinek vizsgálata az időmérleg-felvételek segítségével. Letöltés dátuma: 2020 . 04. 08., forrás: https://www.ksh.hu/docs/hun/xftp/idoszaki/pdf/kult_szokasok.pdf

[32.] Központi Statisztikai Hivatal (2015): Kulturális aktivitás (2003-2015). Letöltés dátuma: 2020. 04. 15., forrás: http://www.ksh.hu/thm/2/indi2_10_2.html Letöltve:

[33.] Központi Statisztikai Hivatal (2019): Letöltés dátuma: 2020. 04.15

[34.] Lenténé Puskás A. - Biró M. - Hidvégi P. - Molnár A. - Lente L. - Pucsok J. M. (2019a): Analysis of the North Great Plain Region's Accommodation Supply with Special Focus on Sport and Wellness Element. Geosport for Society, Vol. 10. No. 1. 15-24. Paper: /gss.1002-046

[35.] Lenténé Puskás A. - Bíró M. - Hídvégi P. - Molnár A. - Lente L. - Pucsok J. (2019c) Analysis of the North Great Plain Region's Accommodation Supply with Special Focus on Sport and Wellness Elements. Geosport for Society, Vol. 10. No. 1. 15-24. Paper: /gss.1002-046

[36.] Lenténé Puskás A. - Hídvégi P. - Tatár A. - Bíró M. - Pucsok J. (2019b): A fürdős és medencés szolgáltatások megjelenése az Észak-alföldi régió szállodáiban. In: Balogh L. (szerk.): Sokoldalú sporttudomány. Debrecen, Debreceni Egyetem Sporttudományi Koordinációs Intézet, 54-62. o.

[37.] Lenténé Puskás A. - Hídvégi P. - Tatár A. - Pucsok J. - Bíró M. (2018): A rekreációs turizmus lehetőségei Magyarországon az Észak-alföldi régióban. In: Balogh L. (szerk.): Fókuszban az egészség. Debrecen, Debreceni Egyetem Sporttudományi Koordinációs Intézet, 19-30.

[38.] Makra G. - Balogh L. (2020): The analytical tools of dementia, the relationsip between dementia and physical activity - a methodological approach: systematic review. Stadium - Hungarian Journal Of Sport Sciences, Vol. 3. No. 1. 1-16. p.

[39.] Müller A. - Barcsák B. - Boda E. J. (2016): Health tourism the cavebath of Miskolctapolca. In: Juhász Gy. - Korcsmáros E. - Huszárik E. (szerk.): Korszerü szemlélet a tudományban és az oktatásban. Gazdaságtudományi szekció: Zborník medzinárodnej vedeckej konferencie Univerzity J. Selyeho 2016 „Súcasné aspekty vedy a vzdelávania". Sekcie ekonomických vied. Komárno, Szlovákia, Selye János Egyetem, 233-245. o.

[40.] Müller A. - Könyves E. (2006): Az egészségturizmus lehetőségei az Északalföldi régióban. Acta Academiae Paedagogicae Agriensis Nova Series: Sectio Sport, Vol. 33. 132-143. 
[41.] Müller A. - Szabó R. - Kerényi E. - Mosonyi A. (2009): Fürdőkutatás a Közép-dunántúli régióban. Acta Academiae Paedagogicae Agriensis Nova Series: Sectio Sport, Vol. 36. 77-87. o.

[42.] Müller A. - Szabó R. (2009):Analysis of Agárd, Komárom and Papa's Thermal bath, According the Guest's satisfaction. Acta Academiae Paedagogicae Agriensis Nova Series: Sectio Sport, Vol. 36. 89-101. p.

[43.] Müller A. - Bácsné B. É. (2018): Az egészséges életmód és a sport kapcsolata. Létavértes, Létavértes SC '97 Egyesület, 96 p.

[44.] Nemzeti Egészségfejlesztési Intézet (2015): Egészségjelentés 2015. Budapest, Nemzeti Egészségfejlesztési Intézet.

[45.] Nemzeti Sportstratégia (Sport XXI. Nemzeti Sportstratégiáról 2007-2020) forrás: http://njt.hu/cgi_bin/njt_doc.cgi?docid=110484.156866

[46.] Tütünkov-Hrisztov J. - Müller A. - Molnár A. (2020): The appearance of sport as a travel motivation in traveling habits. Geosport for Society, Vol. 12. 1. sz. 31-43. p. DOI: 10.30892 /gss.1204-056

\section{Szerzők:}

\section{Czeglédi Hanna Orsolya}

hallgató

Debreceni Egyetem

czegledi.hanna.orsolya@gmail.com

\section{Pucsok József Márton}

egyetemi docens

Debreceni Egyetem, Sporttudományi Koordinációs Intézet pucsok.jozsef@sport.unideb.hu

\section{Lenténé Puskás Andrea}

egyetemi adjunktus

Debreceni Egyetem, Sporttudományi Koordinációs Intézet lpandrea@sport.unideb.hu

\section{Biró Melinda}

egyetemi docens

Debreceni Egyetem, Sporttudományi Koordinációs Intézet biro.melinda@sport.unideb.hu 